\title{
CENSORSHIP OF MOTION PICTURES
}

THE technological advances of the past half century have broadened the means by which knowledge may be spread among men far beyond those known to the framers of the First Amendment. News, opinions, and ideas are now widely disseminated by the radio and the motion picture to the growing exclusion of the more familiar forms of communication. Freedom of speech and press have become, in their traditional sense, of diminished importance because of increasing popular reliance on news gained over the air and from the screen. ${ }^{1}$ As a result, the courts have had difficulty in placing these motern developments in the constitutional pattern.2 Because all questions concerning the radio are referred to one central body, the Federal Communications Conmission, and all cases litigated in the federal courts, a degree of consistency in radio law is already forming. ${ }^{3}$ But movies are subject to regulation on all sides: federal statutes, state and municipal censor hoards, local pulice officials and boards voluntarily set up within the industry. Consequently the present status of movie censorship is oppressive and confused. With eightyfive million Americans attending the movies every week, ${ }^{-1}$ the film industry has attained economic eminence ${ }^{5}$ and respectable years, ${ }^{\circ}$ and today shows signs of increasing restiveness over the censorship under which it is compelled to operate. It is the contention of this Comment that legal censorship by previous restraint is an impediment to full development of the cinema, and that the maturity of the industry now renders this form of control unnecessary.

1. See The Press and the People-A Surech. Fontrate. Aug. 1039, 64.

2. The constitutions of two short-lived European republics made especial provision for the cinema, or for similar methods of expression. Const. of Spunisu Reptour, proclaimed Dec. 9, 1931, Art. 34; Wencar Cosst. of Gersans: Reren, adonted Aug. 11, 1919, Art. 118.

3. The problem of free speech over the radio has already rcceived extencive comment. Caldwell, Legal Restrictions on the Contents of Broadiast Pronrams (1938) 9 An L. Kev. 229; Kassner, Radio Censorship (1937) \& AIn L. Rnv. 99; Caldwell, Frccdon of Speech and Radio Broadcasting (1935) 177 Axwiss 179; Comments (1939) 39 CoL L. Rev. 447; (1933) 46 H.ARv. L. Rew. 987; (1931) 40 Y.LLE L. I. 967; Note (1933) 9 ATR L. REv. 202. See also Revolution in Radio. Fontune, Oct. 1939, 86.

4. Estinate of Motion Picture Producers and Distributors of Anterica (1939) Fruss Facrs 22. In 1930, the peak year, the estimated attendance was 110 million a weel:. The total circulation of daily newspapers in the United States in 1938 was 39,571,839. Eriros and Publisher International Yeargoon for 1939, 112. Of course, it is true that the newspaper statistics are based on number of buyers, not number of readers.

5. The capital investment of the motion picture industry is two billion dollars. Of this, $\$ 1,880,000,000$ is invested in theatres, $\$ 100,000,000$ in studios, $\$ 20,000,000$ in distribution. (1939) Filar Facts 3.

6. The Golden Jubilee of the industry occurred in October, 1939. The demonstration of the Edison Kinetoscope at West Orange, N. J., in October, 18s9, has been recognized as the occasion on which the modern motion picture was born. 
I.

The history of the censorship of motion pictures in America presents an excellent illustration of the confusion caused by attempting to reconcile an unflagging allegiance to abstract liberty with a traditional desire to censor personal morality. ${ }^{7}$ In 1915 the censorship of the motion picture by previous restraint was placed on a firm legal basis by the unanimous decision of the Supreme Court in the case of Mutual Film Corporation v. Industrial Commission. ${ }^{8}$ The case arose under an Ohio statute which created a board of censors for motion pictures, and provided that "all motion picture films to be publicly exhibited and displayed in the State of Ohio" were subject to censorship." The statute further provided that "only such films as are in the judgment and discretion of the Board of Censors of a moral, educational or amusing and harmless character shall be passed and approved by such board." Counsel for appellants argued that the statute contravened the First and Fourteenth Amendments to the Federal Constitution, and Section 11, Article 1, of the Ohio Constitution, providing that "Every citizen may frecly speak, write and publish his sentiments on all subjects, being responsible for the abuse of the right; and no law shall be passed to restrain or abridge the liberty of speech, or of the press." Mr. Justice McKenna disposed of this contention in forthright terms, holding that however didactic films may become there is no impediment to their value and effect in the Ohio statute; that the police power is familiarly exercised in granting or withholding licenses for theatrical performances as a means of their regulation; and that the argument is "wrong or strained which extends the guaranties of free opinion and speech to the multitudinous shows which are advertised on the billboards of our cities." "It cannot be put out of view," he said, "that the exhibition of moving pictures is a business pure and simple, originated and conducted for profit, like other spectacles, not to be regarded, nor intended to be regarded, by the Ohio constitution, we think, as part of the press of the country or as organs of public opinion."10

It is difficult to see how these arguments are any less applicable to newspapers and magazines than to motion picture films. Certainly newspapers

7. Albit, Public Opinion (1939) 260.

8. 236 U. S. 230 (1915). See Notes (1915) 15 CoL. L. Rev. 546, (1915) 13 Micir. L. REv. 515, (1914) 2 VA. L. Rev. 216. Decided at the same time was Mutual Film Corp. v. Hodges, 236 U. S. 248 (1915), in which a similar Kansas statute was upheld.

9. 103 Ohio Laws 1913, 399; Ohro Gen. Code AnN. (Page, 1937) \$ 871 (48-53), $\$ 154(46-47)$. The language of the statute is all inclusive, covering a showing in a city square, or an exhibition of educational films in the public schools of the state. (1915) 2 Ors. Ohyo AtTy. Gen. 1039.

10. Mutual Film Corp. v. Industrial Comm., 236 U. S. 230, 242-4 (1915). Mr. Justice McKenna held further that, since the provisions related only to films intended for exhibition within the state, there was no burden on interstate commerce, and that the delegation of power to an administrative body was proper, under standards which wotld gain precision from "the sense and experience of men." 
may be used for evil, but the Supreme Court has struck down a statute making the publication of a scandalous paper punishable as a nuisance. ${ }^{11}$ Certainly, furthermore, it cannot be said that the New I"ork Tinses or the Saturday Evening Post are any less "a business pure and simple, originated and conducted for profit" than is the cinema industry. ${ }^{12}$ The actual basis for the Court's abandonment of its declaration of eight years previous, that the aim of the constitutional guaranties was to prevent all previous restraints, ${ }^{13}$ seems rather to be two-fold: one, the tradition of regulation by license of theatrical performances, and, two, a belief induced by the nickolodeon stage of the motion picture, that it was comparable to a sideshow or circus.

The recognized power to license and thereby to regulate theatrical exhibitions under the police power very probably originated in an anomaly of English law, the rigorous censorship of the drama which was left unimpaired during the development of the freedom of speech and press. During the 16th and early 17th centuries the stage enjoyed a status comparable to that of the press. ${ }^{14}$ But there is and has been a strong tendency in the English middleclass climate of opinion, dating from Cromwellian times, to consider the stage a low form of entertainment and to bracket actors in the same category with ragabonds and beggars. ${ }^{15}$ And in 1737 Sir Robert Walpole, to quict the satire of his administration prevalent in the theatres of London, persuaded Parliament to pass a bill giving the Lord Chamberlain the statutory power of licensing all stage plays. ${ }^{16}$ The Theatres Act of $1843,{ }^{17}$ with minor amendments, leares this power basically unchanged. Had it not been for these two statutes, it is quite possible that "pulpit, press, and play would today be on a footing of equality." 18 The stifling effect of this censorship is attested by the quality both of the plays banned and of the authors who have fought

11. Near v. Minnesota, 283 U. S. 697 (1931).

12. The net profits of the New York Times Co. for the years 1934-36 averaged $\$ 1,040,667$ a year. Enrtor AxD Prbussaes. July 22, 1939, 16. The net earnings of the Curtis Publishing Co., publishers of the Saturday Evening Post, for the six months

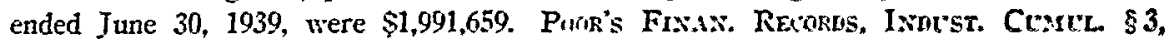
Oct. 2, $1939,119$.

13. Patterson v. Colorado, 205 U. S. 454,462 (1907). The IIufual case marlied the only instance in which the Court has sustained previous restraint as constitutional. Sce Rosexberg, Censorship IN the United Strates (1928) 15; Erssst asi Sealgle, To THE PURE (192S) 28.

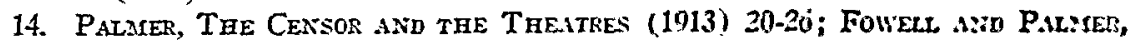
Cexsorship in Exgland (1913) 7S-9.

15. See Fon'elr and PalsIer, op. cit. supra note 14, at S0-93; PaLzers, op. cit. supra note 14, at 28; Thoarpson, The Controversy Between the Pumitans and zie Stage. (1903).

16. The Theatres Act of $1737,10 \mathrm{GEO}$. II, c. 2s, quoted in appendis, Fowell A:id Patater, Censorship in England (1913) 368.

17. An Act for Regulating Theatres, (1843) 6 \& 7 VIcr., c. 68.

18. PALIIER, op. cit. sipra note 14 , at 20. 
it. ${ }^{19}$ With such a background in English law, and with a Puritan heritage in America which frowned on the stage, it is understandable that the theatre in the early years of this country was regarded as a low form of entertainment, to be licensed by. each town or city in the interest of morality and decency. ${ }^{20}$ Occasionally a court, interpreting a state constitution, declared the drama to be protected from "previous restraint" censorship, ${ }^{21}$ but in the vast majority of cases control by license of the theatre was considered an eminently legitimate use of the police power ${ }^{22}$

The other probable explanation for the Mutual decision lies in the fact that twenty-five years ago, when the case arose, there was a tendency to regard the primitive motion picture as a disreputable form of entertainment. ${ }^{23}$ The fabulous rise of the industry in the succeeding years is a matter of record $; 24$ the improvements in photography and projection, in the development of technicolor and talking pictures, are matters of common knowledge. Five newsreel companies today each publish one hundred and four releases a year. ${ }^{25}$ The March of Time has brought the technique of the news magazine to the screen. ${ }^{26}$ The documentary film is only now in process of development

19. See generally Knowles, The Censor, The Drama and the Fila 1900-1934 (1934) 13-166; Fowell ANd PALMER, op. cit. supra note 14, at 184-352, 374-379; PALMER, op. cit. supra note 14.

20. Either a play had to satisfy the licensing officer before a permit was issucd for its performance; or else the license of the theatre was revocable at will, if the licensing body considered a theatrical performance to be contra bonos mores. Commonwealth v. McGann, 213 Mass. 213, 100 N. E. 355 (1913); Bainbridge v. Minneapolis, 131 Minu. 195,154 N. W. 964 (1915). In other cities there were no restrictions other than the possibility of ex post facto prosecution for violation of statutes forbidding indecent performances.

21. Dailey v. Superior Court, 112 Cal. 94, 44 Pac. 458 (1896). Mayor Gaynor vetocd a New York City movie censorship ordinance in 1912 as an unconstitutional interference with freedom of the press. Veto message quoted in Ennst and Lorentz, Censonen, Till Private Life of the Movie (1930) 166; Rosenderg, Censorship in tue United Statis (1928) 12.

22. Commonwealth v. McGann, 213 Mass. 213, 100 N. E. 355 (1913); Bainbridge v. Minneapolis, 131 Minn. 195, 154 N. W. 964 (1915) ; Thayer Amusement Co. v. Moulton, 7 A. (2d) 682 (R. I. 1939); Xydias Amusement Co. v. Houston, 185 S. W. 415 (Tex. Civ. App. 1916) ; see Chicago v. Kirkland, 79 F. (2d) 963 (C. C. A. 7th, 1935). See generally Grant and Angoff, Massachusetts and Censorship (1930) 10 B. U. L. Rev. 36, 162, 185; 3 McQuimlin, Municipal Corporations (2d ed. 1928) \$1056.

23. See Higgins v. Lacroix, 119 Minn. 145, 137 N. W. 417 (1912). For the carly history of movie censorship, see Ramsaye, A MrLion aNd ONe Nights (1926) c. 47.

24. See Jacods, The Rise of the American Fum (1939) ; Bardecie and Brasillach, The History of Motron Pictures (1938) ; Lewis, The Motion Picture IndustrX (1933); HAMpton, History of the Movtes (1931).

25. Fox Movietone News, M. G. M. News of the Day (formeriy Hearst Metrotone News), R. K. O. Pathe News, Paramount News, and Universal News.

26. In addition to producing its monthly issues, the March of Time has begun work on its first feature length production, The Ramparts $W_{\mathcal{e}}$ Watch, an adaptation of Major George Fielding Eliot's book. N. Y. Times, Sept. 16, 1939, p. 20, col. 6. 
as an adjunct to education and to the formation of public opinion. ${ }^{27}$ Annually nearly five hundred feature pictures are produced in this country, many of them of a high literary and artistic merit.28 Clearly science has given birth to a new art of extraordinary possibilities. ${ }^{20}$ But in 1915 not even the Supreme Court was prescient enough to realize this.

\section{II.}

At the time of the Mutual decision, three of the forty-eight states had their own censor boards..$^{30}$ Since then, six more have provided for previous restraint censorship. ${ }^{31}$ The number of states with censorship boards would not of itself be impressive if the other states were immune from their influence. But the peculiar nature of the industry makes such isolation impossible. There are only a limited number of prints made of each individual film, and these prints are apportioned to some thirty exchanges for distribution in the area served by each exchange. All but six of these exchanges serve territory in more than one state, several of them in as many as five states. ${ }^{32}$ Furthermore, to have a film cut or mutilated by any one state means not only a direct material loss to the producer; it carries as well an unappraisable but distinet

27. See Rotha, Doccareataky Find (1939). Well-lnown documentary films include Nanook, Mroana, Man of Aran. The Plow that Brole the Plains, The River, Sfanish Earth, The 500,000,000, and The City.

28. In 1938, 491 feature pictures received the approval of the Hays office, crelusive of foreign-made films and reissues. H.1ys, ANwr..1 Reront (1939) 7.

29. See Thorp, Ayrertca at the liovies (1939); Bardecue nzod Brastrack, Tre History of Miotion Pictures (1938); Arnhem, Filal (1933).

30. Pennsylvania (1911), PA. Stat. AxN. (Purdon. 1930) tit. $4 \$ \$ 41-5 \$$, tit. 71, $\S \S 12,62,119,356$; Ohio (1913), Oнlo Gen. Cone ANw. (Page, 1937) $\$ \S \$ 71$ (43-53), $\$ \$ 154$ (46-47); Kansas (1913) Kin. Rev. Stat. Aw. (1935) c. 51, 8ुS 101-112, c. 74, $\$ \$ 2201-09$. See generally Legis. (1930) 44 HaRv. L. KEv. 113.

31. Maryland (1916), MID. Axw. Cone (Bagby, 1924) art. 66A; amended, Mrv. Core Pub. Gen. Laws (Flack, Supp. 1935) art. 66A, \$\$7, 10, 11 ; amended Laws 1939, c. 430; New York (1921) N. Y. Edrc. L.aW $\$ \$ 10 \$ 0-1092$; Florida (1921), Fla. Coss. Ge:* Laws ANn. (Skillman, 1927) $\$ \$ 35 \$ 4-86$, 7719; Virginiz (1922), VA. Cone A:m: (Michie, 1936) $\$ \$ 378 b-378 j$; Louisiana (1935), La. Gex. St.n. A:iz. (Dart, 1939) \$\$9594.11-9594.17. The Louisiana board, a political creation, has never come into oparation. Massachusetts, after censorship was defeated nearly 3 to $I$ in a referendum in 1922, achieved the same result under a Lord's Day Observance statute, MIsss. Gen: Laws (1932) c. 136, $\$ \$ 1-4$, which vests censorship powers in a bureau of the state police. Since nearly all films of general distribution will be shown on Sundays, these films are all submitted to the board. A Connecticut statute [Conn. Pub. Acts 1925, c. 177] provided for registration of all films and payment of a tax thereon, with provision for revocation of registration if the films offended certain standards. The statute was upheld in Fox Film Corp. v. Trumbull, 7 F. (2d) 715 (D. Conn. 1925), dismisscd by stipulation, 269 U. S. 597 (1925) ; (1925) 35 Yale L. J. 109. It was repealed in 1927, Conn. Pub. Acts 1927, c 318. The Florida Statute has been found unconstitutional. See note 41, sisfra.

32. Thus West Virginia and Kentucky see films censored in Ohio, Missouri those censored in Kansas, Rhode Island, Vermont and New Hampshire those cut in Massachusetts. See map of exchange areas, (1939) FInx FActs 17. 
diminution of the entertainment value of the film in that area. ${ }^{38}$ Thus the producers, and particularly the administrators of the Production Code, are faced with the problem of producing movies that will meet the individual peculiarities of different state boards, operating under different acts. And even where statutory standards are identical, boards in two different states will, in practice, rarely make the same deletions. ${ }^{34}$

The statutes under which these boards operate are so general in their terminology that their interpretation is largely left to the discretion of the members, who are usually three residents and citizens of the state "well qualified by education and experience." 35 Although the examination fees ${ }^{30}$ have proved to be a sizeable source of revenue to the state, ${ }^{37}$ the primary purpose of these statutes is to protect the inhabitants of the state from unwholesome and indecent motion pictures. Many of them provide that a film or any part thereof may be censored if it falls within the statute, without regard to the theme of the film as a whole. ${ }^{38}$ In literature the courts have

33. Deletions of dialogue in talking pictures interfered with the plot sequence to a greater extent than deletions in silent pictures. See Lewis, The Morion Protune IndusTRY (1933) 380 .

34. An informal survey by the M. P. P. D. A. showed that of the total cuts in a given period only a small percentage were made by a majority of the state boards. Even where the single word "immoral" is in question, neither boards nor courts can agree on the meaning to be accorded it. Fox Film Corp. v. Collins, 236 Ill. App. 281 (1925) (rcpeated shooting in action of film held to bring it within ordinance prohibiting immoral pictures). See In re Appeal from Board of Censors, Phila. C. P. Ct. No. 6, Phila. Legal Intelligencer, Nov. 26, 1937, p. 1, col. 2 (suggesting that film exciting sympathy for Loyalist Spain, if not current events film, would be immoral as inciting to violation of Neutrality Act).

35. Kax. Rev. Stat. Ans. (1935) c. 74, $\$ 2201$. The clause in practice is meaningless, the appointments being largely political. In New York, Ohio, and Pennsylvania the boards are a division of the department of education. The salaries of the members range from $\$ 2100$ for the chairman and $\$ 1800$ for other members in Kansas to $\$ 4800$ for the chairman and $\$ 4500$ for the others in Pennsylvania. KAN. Rev. Stat. ANN. (1935) c. 74, $\S 2205$, PA. Stat. Axw. (Purdon, 1930) tit. 71, §119. For representative standards, sec Mp. Code A AN. (Bagby, 1924) art. 66A, $\$ 6$.

36. In New York the fees are $\$ 3$ for each 1,000 feet or fraction thereof of original film and $\$ 2$ for each additional copy thereof. N. Y. Evuc. LAw \$1086. In Maryland the fee is $\$ 2$ for the original, and $\$ 1$ for each additional copy. Mo. Code Pun. Gen. Laws (Flack, Supp. 1935) art. 66A, $\$ 11$. Even if the income is nearly four times the cost of the administration of the censor board, it is insufficient to compel the conclusion that it was intended by the legislature as a revenue measurc. State e.r rel. Brewster v. Ross, 101 Kan. 377, 166 Pac. 505 (1917).

37. In New York these fees, from the establishment of the board of censors in 1921 to June 30,1938 , had amounted in net revenue to the state to $\$ 2,537,322$. RErokT OF TUE Motion Picture Division (1938) 9. The Ohio act provides that $50 \%$ of the net return from censorship fees be used for the promotion of Ohio and for the development of a library of educational films. OHio Gen. Code ANN. (Page, 1937) \& 871-48a.

38. N. Y. Educ. Law §1082; VA. Code ANn. (Michie, 1936) §378d. Even if the statute is silent, the censor board will look to the line or the scenc, rather than to the film as a whole. Cf. People $c \cdot x$ rel. Guggenheim v. Chicago, 209 Ill. App. 582 (1918). 
lately arrived at the wiser conclusion that a questioned book must be judged as an entity. ${ }^{39}$ The boards have yet to realize that they cannot effectively censor the underlying theme.40

When challenged, the constitutionality of these boards has been sustained by the courts, which have held that regulation of the content of all films designed for public exhibition within the state is a proper exercise of the police power. ${ }^{41}$ This regulation has been applied alike to newsreels and fulllength films. Only once since the Mitual case has a court been requirel to pass squarely on the validity of censoring newsreels. On that occasion the New York courts upheld the censorship on the ground that inasmuch as newsreels are shown in "a public place of amusement," they are not a part of the press. ${ }^{42}$ Of the state statutes, only New York, Pennsylvania and Kansas now exempt "current event" films from the operations of censorship." Ex-

39. United States v. One Book Cllysses. 72 F. (2d) 705 (C. C. A. 2d, 1934), aff g, 5 F. Supp. 182 (S. D. N. Y. 1933) ; United States v. Levine, 83 F. (2d) 156 (C. C. A. $2 d, 1936)$. "The standard must be the likelihood that a work will so much arouse the salacity of the reader to whom it is sent as to outweigh any literary, scientific or other merits it may have in that reader's hands; of this, the jury is the arbiter." L. Hand, J., \$3 F. (2d) at 158. See Alpert, Iudicial Censorship of Obscene Litcrature (1938) 52 HARV. L. RET. 40.

40. See Albig, Public Opinion (1939) 263.

41. MLutual Film Corp. v. Industrial Commission, 235 U. S. 230 (1915); Mtutuzl Film Corp. v. Industrial Commission, 236 C. S. 247 (1915); Mutual Film Corp. v. Hodges, 236 U. S. $24 S$ (1915); Fox Film Corp. v. Trumbull, 7 F. (2d) 715 (D. Conn. 1925); State $c x$ rel. Brewster v. Ross, $101 \mathrm{Kan} .377 .165$ Pac. 505 (1917); United Artists Corp. v. Mills, 136 Kan. 33, 12 P. (2d) 785 (1932) ; Pathe Exchange v. Cobb, 202 App. Div. 450, 195 N. Y. Supp. 661 (1922) ; Buffalo Branch, Mfutual Film Corp. v. Breitinger, 250 Pa. 225, 95 Atl. 433 (1915) ; In rc Franklin Film MIfg. Corg. 253 Pa. 422, 98 Atl. 623 (1916); In rc Goldwyn Distrib. Corp., 265 Pa. 335, 108 . Atl. 816 (1919); In re Fos Film Corp., 295 Pa. 461, 145 Atl. 514 (1929). But the Florids statute, because of its unique provision that only films approved either by the National Eoard of Review or by the New York board of censors might be shown in the state, has been ruled unconstitutional. State ex rel. Cummins v. Coleman, Circ. Ct.. 11th Jud. Circ., Mrsy 1, 1937. See generally Notes (1930) 64 A. L. R. 505, (1916) 1 Cors. L. Q. 173. (1915) 14 Mrrer. L. Rev. 139.

42. Pathe Exch. v. Cobb, 202 Apr. Dir. 450,195 X. Y. Surp. 601 (3d Dep't 1922), aff'd, 236 N. Y. 539, 142 N. E. 274 (1923). See Notes (1923) 32 Yale L. J. 185, (1922) 71 U. of PA. L. REv. 58, 64. It is problematical whether this test would stand up, if an attempt were made to censor the United Press ticker news which for a time was flashed on screens of a chain of New York city newsreel houses. Newsreels were later exempted from censorship in New York. See note 43, infra.

43. N. Y. Entc. LAw \$10\$3a; PA. Stat. Axs. (Purdon, 1930) tit. 4, $\$ 43$; Ki::. Rev. Stat. Axs. (1935) c. 51, \$103. Although the Virginia Board has discretionary power to exempt newsreels [VA. CODE ANN. (Michie, 1936) §378d], newsreels are in practice inspected by the board. These exemptions were created by amendments to the original acts passed between 1922 and 1928, when the newsreel had begun to assume its present form. It seems probable that films like the March of Time will be held to fit into such a category. (1934) OPS. N. Y. ATTY. GEN. 36s; cf. In re Appeal from Bisaril of Censors, Phila. C. P. Ct. No. 6, Phila. Legal Intelligencer, Nov. 26, 1937, p. 1, cul. 2. See (1926) Ops. N. Y. Atry. Gen. 224; (1934) Ors. X. Y. ATry. Ges. 358; (1984) 98 Just. P. 551 ; Note (1935) 179 L.aw Trares 270. 
emptions are granted under several of the statutes to scientific films for use by the learned professions, if not to be exhibited at any place of amusement ;4 and exemptions are permitted at the discretion of the board for films intended solely for educational, charitable, or religious purposes. ${ }^{45}$ Exemptions for news films, however, are the exception, not the rule. ${ }^{46}$

Much of the justification for state censor boards is based on a fear that a relaxation of legal standards would have a markedly deleterious effect on the morals and behaviour of movie-going children. ${ }^{47}$ The wisclom of such a contention seems open to challenge. ${ }^{48}$ The large number of parents groups and other unofficial bodies which classify films according to their suitability for exhibition to the young have gained widespread popular support, and the Hays office has been anxious to cooperate with these groups. ${ }^{40}$ This method of meeting the problem seems preferable to the British system of semi-official classification of films for universal or for only adult view. ${ }^{\mathbf{5 0}}$

The records of the boards of censors reveal no lack of hesitancy in exercising their power. In Ohio and Pennsylvania they have banned films and

44. N. Y. Educ. Law \$1083b; Pa. Stat. AnN. (Purdon, 1930) tit. 4, \$57; VA. Code Ann. (Michie, 1936) $\$ 378$ d.

45. Kan. Rev. Stat. Ann. (1935) c. 51, §110; Md. Ann. Code (Bagby, 1924) art. $66 \mathrm{~A}, \S 22 ; \mathrm{N}$. Y. Educ. LAw $\$ 1083 \mathrm{~b}$.

46. In the period from Oct. 1, 1937, to Sept. 30, 1938, Massachusetts required 13 deletions from newsreels and the March of Time. Mass. Dept. of Public Safety, List of Titles of Motion Pictures which have been Approved, Oct. 1, 1937, to Sept. 30, 1938. The newsreels have frequently been used for propaganda purposes, notably to defeat Upton Sinclair in the California gubernatorial election of 1934. See Alsic, Pumtic Opinion (1939) 369.

47. The Payne fund studies, twelve studies "of the influence of motion picturcs upon children and youth" published in 1933 by the Committee of Educational Rescarch of the Payne Fund at the request of the National Committee for the Study of the Social Values in Motion Pictures, tended to substantiate such a belief. Courts repeatedly refer to the children who may see a film when reviewing censorship decisions. See Block v. Chicago, 239 I11. 251, 87 N. E. 1011 (1909) ; People exr rel. Konzack v. Schuettler, 209 Ill. App. 588 (1918) (Film: Margaret Sanger in Birth Control) ; United Artists v. Thompson, 339 Ill. 595, 171 N. E. 742 (1930) ; American Committee on Maternal Welfare, Inc. v. Mangan, 257 App. Div. 570, 14 N. Y. S. (2d) 39 (3d Dep't 1939). But cf. note 48, infra.

48. Professor Adler has pointed out the fallacious basis of the Payne stucties, and indicated that there is no data now extant which shows any pronounced bad effect from the cinema on the youth of this country. AdLer, ARt and Prudence (1937) pt. III, summarized in Moley, ARE We Movie-Made? (1938).

49. See Thorp, America at the Movies (1939) 177-182.

50. The Hays office opposes such a classification as placing an undue emphasis on the "adult" category of films. See generally, Knowles, The CEnsor, Tue Dradra ANI the Film (1934); Causton and Young, Keeping It Dark (1931); (1926) 90 Just. P. 545; annual reports of the British Board of Film Censors (1934) 98 Just. P. 551, (1933) 97 Just. P. 179, (1929) 93 Just. P. 333; Address of Rt. Hon. Lord Tyrrell of Avon, President of the British Board of Film Censors, a semi-official body, June 24, 1936, dwelling on the dangers of introducing political controversy into the films. The March of Time is on occasion banned in England. True, June 1, 1936, 40; N. Y. Times, Oct. 13, 1938, p. 9, col. 3. 
newsreels considered pro-labor. ${ }^{51}$ In Kansas a speech by Senator Wheeler opposing the bill for enlarging the Supreme Court was ordered cut from the March of Time. ${ }^{52}$ A documentary film of the civil war in Spain entitled Spain in Flanes was banned in Pennsylvania, with the proviso that if the words "Fascist," "Nazi," "Italian," "Rome," "German," "Berlin," and the like be deleted wherever they appear, the pictures would be approved. This decision was reversed in the courts on the ground that the film, being documentary, was one of current events ${ }^{53}$ and therefore allowable in Pennsylvania. In Ohio Spain in Flanes was banned with this comment: "The picture itself did not contain any harmful propaganda. However, the dialogue of the narrator made the picture, we consider, very harmful. We suggest that the narrators, in reporting on this subject . . . keep their remarks neutral, or we will find it necessary to make eliminations." banned in New York, and the courts would not disturb the decision. Ju Juge Hill, in a strong dissent, said: "It is further argued that the subject of sterilization should not be given publicity. Such an argument presents the issue of whether our people may govern themselves or be governed; whether arguments for and against proposed and impending legislation may he presented direct in the public prints, on the stage and by films, or whether a Commission or Commissioner is to determine the limit and character of the information to be given to the public."50

51. Mainly during the coal strikes of 1920. Deinard, Sonc Legal and Historical Aspects of Motion Picture Censorship (Unpublished thesis in Harvard Law Schnol Library, 1922) 92, 93. In 1937 a Russian film, Of Greater Promise, was banned in Ohio because "the picture encourages social and racial equality, thereby stirring up rasial hatred . . . all the above doctrines are contrary to accepted codes of American life." Quoted in American Civil Liberties Union pamphlet on motion pieture cencorship, Dec. $1,1938$.

52. The reason given was: "We feel this dialogue is partisan and biased." Governor Hurman refused to intervene, but after a determined popular outcry the board was induced to rescind its decision. The president of Pathe News commented that it is not news "when one of these boards interferes with a newsreel." Litering Digest, Miay 1, 1937, 3-4.

53. In re Appeal from Board of Censors, Phila. C. P. Ct. No. 6, Phila. Legal Intelligencer, Nov. 26, 1937; (1938) S6 U. of PA. L. KEx. 305. Judge Levinthal's scholarly opinion questions the constitutionality of censorship of newsreels.

54. Quoted in Literany Digest, May 1, 1937, 3. The official grounds for refucal were that the film stirred up race hatred and was anti-religious. An attempted appral to the courts was defeated by failure to institute proceedings within ten days of the final order of the board, as required by statute. North American Committee to Aid Spanish Democracy v. Bowsher, 132 Ohio St. 599, 9 N. E. (2d) 617 (1937).

55. Foy Productions v. Graves, 253 App. Div. 475, 3 N. Y. S. (2d) 573 (3d Dep't 1938 ), aff'd, 278 N. Y. 498, 15 N. E. (2d) 435 (1938). The film Tomorrants Childres: attacked sterilization, and portrayed inter alia a Catholic priest preaching a sermon against it. A courtroom scene in which the judge is shown as currupt and venal was one of the grounds for the ban.

56. Foy Productions v. Graves, 253 App. Div. 475, 483, 3 N. Y. S. (2d) 573, 583 (3d Dep't 1938). 
The French cinema version of Jean Giono's novel Regain, entitled Harvest, was prohibited by the New York censors. When the film was shown, after reversal of their decision by the Board of Regents, one of the leading New York critics called it a "motion picture of abiding beauty, honesty and humor" which "belongs among the really memorable achievements of the screen . . Harvest is profoundly and even passionately moral." ${ }^{67}$ The film The Birth of $a B a b y$, presented by the American Committee on Maternal Welfure to depict maternity in "a clean, dignified and reverent manner," 58 was banned in Virginia and New York. ${ }^{50}$ Clearly under the statutes, a board of censors "may ban as immoral a film dealing with social sex problems, human biology or the procreative function even when not obscene or indecent."

In the event a film is rejected by the board, the statutes specify that the applicant may demand a reexamination, and if the rejection is affirmed, may then appeal to a designated court. ${ }^{61}$ Provisions for judicial review, however, give little relief from oppressive decisions. One reason for this is the nature of the industry; a film, especially if it is a newsreel, loses value rapidly in the time required for a judicial hearing. The other reason is the unanimous refusal of the courts to substitute their judgment for that of the censors unless the examining officials acted in bad faith, capriciously, or arbitrarily. ${ }^{02}$

57. Howard Barnes, in N. Y. Herald Tribune, Oct. 3, 1939, p. 18, col. 2. Two other French films warmly received by the critics have been banned in New York: The Puritan, an adaptation of Liam O'Flaherty's novel, and Remous. (1938) 97 NEw Repuntic 215. The ban on Remous was upheld by the Appellate Division, Mayer v. Byrne, 256 App. Div. 431, 10 N. Y. S. (2d) 794 (3d Dep't 1939). For other films banned in New York, see Weinberg, Censored. Some of the Films New York Will Never Sec, CuE, May 8, 1937, 10. In general, owners of foreign films, unless they expect to sell their films to the large theatre circuits where it is required, do not submit them to the Hays office for a seal of approval; but those films are classified by the Legion of Decency in their weekly lists.

58. Hill, P. J., and Heffernan, J., dissenting in memorandum, American Committce on Maternal Welfare, Inc. v. Mangan, 257 App. Div. 570, 573, 14 N. Y. S. (2d) 39, 42 (3d Dep't 1939).

59. The Virginia ruling was upset in the City Circuit Court. Civil Linerties QunnTERLY, Dec. 1938, 3. The New York ban was upheld by a 3-2 decision of the Appellate Division. American Committee on Maternal Welfare, Inc. v. Mangan, 257 App. Div. 570,14 N. Y. S. (2d) 39 (3d Dep't 1939).

60. Hill, P. J., concurring in Mayer v. Byrne, 256 App. Div. 431, 432, 10 N. Y. S. (2d) 794, 795 (3d Dep't 1939).

61. To the court of common pleas in Pennsylvania [PA. Stat. ANN. (Purdon, 1930) tit. 4, §54], or to the Baltimore City Court in Maryland [MD. Anv. Cope (Bagby, $1924)$ art. 66A, \$19]. In New York the appeal is to the Board of Regents, whose decision is reviewable on certiorari in the Appellate Division of the Supreme Court. N. Y. Educ. Law \$ 1084.

62. Mid-West Photo-Play Corp. v. Miller, 102 Kan. 356, 169 Pac. 1154 (1918); State ex rel. Brewster v. Crawford, 103 Kan. 76, 173 Pac. 12 (1918); Public Welfare Pictures Corp. v. Lord, 224 App. Div. 311, 230 N. Y. Supp. 137 (3d Dep't 1928); Eurcka Productions v. Byrne, 252 App. Div. 355, 300 N. Y. Supp. 218 (3d Dep't 1937); Foy Productions v. Graves, 253 App. Div. 475, 3 N. Y. S. (2d) 573 (3d Dep’t 1938), aff'd, 
Cases in which the boards have been upheld are legion; cases in which they have been overridden can be counted on the fingers of one hand. ${ }^{.3}$ So long as some evidence is present upon which the board's action might have been based, so long as it is possible that three citizens of the state may honestly consider a film indecent, ${ }^{64}$ the courts will not interfere. ${ }^{65}$

The extent of the deletions made by a board of censors in one year is clear from the following tabulation from New York of the grounds for eliminations, and the number of eliminations made on these grounds, in the perind from July 1, 1937 to June 30, 1938: Indecent, 364 deletions; Inhuman, 28; Tending to incite to crime, 60; Immoral or tending to corrupt morals, 265: Sacrilegious, 55 ; Total deletions, 772 . In the same period 23 films were condemned in toto. ${ }^{66}$

\section{III.}

Another and equally powerful form of film censorship is that set up by municipal ordinance in states where there is no state board of censorship. The Motion Picture Almanac for 1939 lists over $\mathbf{5 0}$ censorship boards in the larger cities of the country, ${ }^{67}$ but some of these, at least, are quiescent or merely titular bodies. Of the rest, the vast majority are manned by policemen or policewomen. And even where there is no local censorship, the chief of police or commissioner of licenses will occasionally refuse a permit to a film he considers objectionable. In some states the power of censorship is given by statute to local authorities. ${ }^{68}$ In other states the power is found by implication in a delegation of regulatory power to municipalities, by general statu-

278 N. Y. 498,15 N. E. (2d) 435 (193S) ; MTayer v. Eyrne, 255 App. Div. 431, 10 N. Y. S. (2d) 794 (3d Dep't 1939); American Committee on Maternal Welfare, Ine. v. Mangan, 257 App. Div. 570, 14 N. Y. S. (2d) 39 (3d Dep't 1939); In re Franlslin Film Mfig. Corp., $253 \mathrm{~Pa}$. 422, 98 Atl. 623 (1916); In re Goldwyn Distributing Corp., $265 \mathrm{~Pa}$. 335, 108 At1. 816 (1919).

63. State $e x$ rel. Midwestern Film Exch. v. Clifton, 118 Ohio St. 91, 160 N. E. 625 (1928) (ban of film based on general knowledge, rather than on inspection of film, held non-compliance with statute); In re Appeal from Beard of Censors, Phila. C. P. Ct. No. 6, Phila. Legal Intelligencer, Nov. 26, 1937, p. 1, col. 2 (film held to be in current events category and thus exempt); the reversal of the Virginia board's ban on the Birfh of a Baby, Civil LIBerTies Quarterly, Dec. 193S, 3.

64. "It is a matter of opinion whether this picture is decent or indecent, and where there is room for an honest opinion, this court should not interiere." Scltencl, J., in American Committee on IIaternal Welfare, Inc. v. Mangan, 257 App. Div. 570, 572, 14 N. Y. S. (2d) 39, 41 (3d Dep't 1939).

65. The courts frequently indicate anxiety over the possible effect of a challenged film on an audience in which children are present. See note 47 , sufra.

66. Report of the Miotion Picture Drvision (1938) 7. Eefore the Production Code was enforced in Hollywood the number of deletions was three times as large. See Wrat Shocked the Cexsors in New YORK (1933), published by National Council on Freedom from Censorship.

67. International Motion Picture Alainanac (1939-40) 1137-39.

68. LA. GeN. Stat. (Dart, 1939) $\$ \$ \$ \$ 43-5845$ (superseded by $\$ \$ 9594.11-9594.17$, setting up the as yet inoperative state censor board); 310 . Rev. Srat. (1939) $\$ 6486$, [64. 
tory grant ${ }^{69}$ or in the state constitution. ${ }^{70}$ The actions of local censor boards are apt to be even more capricious than those of the state censors, as the boards are infinitely more susceptible to any locally powerful religious, social or patriotic organization. It is easy for these groups to make their power felt in a relatively compact community. ${ }^{71}$

Another form of municipal regulation nearly indistinguishable from the municipal censor board is the requirement of a permit for all theatrical exhibitions, including motion pictures. A recent Rhode Island case ${ }^{72}$ upheld the action of the police amusement inspector in Providence in refusing a license to the Russian-made, anti-Nazi film Professor Mamlock on the ground that it was communistic propaganda, that it tended to provoke class and race hatred, and that it had not the approval of the National Board of Review. ${ }^{73}$ The statute gave the police an absolute discretion to grant or refuse a license for a film, without requiring them to formulate rules and regulations for stuch films or to hold hearings or to give the applicant an opportunity to produce evidence in support of the application. ${ }^{74}$ The Supreme Court of Rhode Island held that this statute was constitutional, and that the refusal, without a hearing, to license the film would not be disturbed, since there was evidence in

69. The mayor, aldermen and common council of any city "may license and regulatc any exhibitions therein." Conn. Gen. Stat. (1930) c. $169, \$ 2929$. See Ill. Ann. Stat. (Smith-Hurd, 1934) c. 24, $\$ 65.40$; Minn. Stat. (Mason, 1927) $\$ \S 1186,1187$. But the general welfare clause of the New Jersey Home Rule Act was held not to authorizc censorship of plays or motion pictures. Public Welfare Pictures Corp. v. Brennan, 100 N. J. Eq. 132, 134 Ati. 868 (1926), (1927) 11 MiNN. L. Rev. 381.

70. Xydias Amusement Co. v. Houston, 185 S. W. 415 (Tex. Civ. App. 1916).

71. The existence of a state board of censors will render any attempt at municipal censorship void. American Committee on Maternal Welfare, Inc. v. Cincinnati, 11 Ohio Ops. 366 (C. P. 1938) ; Epoch Producing Corp. v. Davis, 19 Ohio N. P. (N.S.) 465 (C. P. 1917). But the passage of a film by a municipal censor board is no bar to prosecution under an ordinance forbidding the exhibition of obscene or indecent films. Seattle v. Smythe, 97 Wash. 351, 166 Pac. 1150 (1917) ; sce Anderson v. City of Hatticsburg, 131 Miss. 216, 94 So. 163 (1922). Chicago has long had one of the strictest of municipal ordinances. It has been frequently upheld in the courts. Block v. Chicago, 239 I11. 251, 87 N. E. 1011 (1909); Mutual Film Co. v. Chicago, 224 Fed. 101 (C. C. A. 7th, 1915); United Artists v. Thompson, 339 Ill. 595, 171 N. E. 742 (1930). Other ordinances, dating from a time when the National Board of Review was at the height of its influence, specify that only such films as have not been passed by the National Board need be inspected by the local censors. See Legis. (1930) 44 Harv. L. Rev. 113, 116, n. 31.

72. Thayer Amusement Co. v. Moulton, 7 A. (2d) 682 (R. I. 1939).

73. A Rhode Island statute [GEN. Laws $(1938)$ c. $362, \$ 2$ ] specifies that a licenso shall not issue for a motion picture to be shown on Sunclay unless the film has the approval of the National Board of Review.

74. R. I. GeN. Laws (1938) c. $362, \S \S 1,2$. Under this statute Providence has rccently banned the stage plays $O f M i c e$ and $M e n$ and The Women, and forbidden the second-run exhibition of Blockade. 
the record upon which the decision could have been based and since the court on certiorari will neither weigh the evidence nor see the film. ${ }^{\text {is }}$

Still further methods for municipal control of motion pictures are made possible by ordinances which make any permit or license revocable when necessary for the furtherance of decency and good order. ${ }^{70}$ In this way the license of any theatre may be withheld or revoled if a film offensive to the local authorities is shown therein. The burden of deciding what may or may not be offensive is thereby given to the local exhibitor, who must guess correctly on pain of losing his license. The New York courts, however, have held that a similar provision did not give the New York City Commissioner of Licenses power to revoke the license of a theatre for the presentation of an improper play, noting that under the penal laws such action is punishable as a misdemeanor. ${ }^{77}$ In general, the courts are as reluctant to disturb municipal censorship as they are that of the state boards. ${ }^{78}$

The danger of unlimited municipal control over motion pictures is well brought out when a film which touches on controversial topics appears. The recent movie Blockade, a fictional and reasonably well disguised treatment of the Spanish Civil War, which ventured to condemn the bonbing and starvation of women and children, was infuriating to adherents of General Franco who considered it a pro-Loyalist movie. The film was actively boycotted and picketed by the Knights of Columbus and by Catholic groups throughout the country. ${ }^{79}$ Attempts to ban or censor the film were made in Boston, Omaha, Kansas City, and elsewhere. The entire film was barred from Somerville, Massachusetts, and a license was refused for second-run

75. The court emphasized the location of the licensing statute in the general laws of the state, observing that it was "significantly" grouped with the intosicating liquors chapter, the bowling alleys, billiards and shouting galleries charter, and the pawnbroters chapter. Thayer Amusement Co. v. Moulton, 7 A. (2d) 682, 686 (R. I. 1939).

76. See Bainbridge v. Minneapolis, 131 MFinn. 195, 154 N. W. 264 (1915); Edelstein v. Beil, 91 Mfisc. 620, 155 N. Y. Supp. 590 (Sup. Ct. 1915); Genesee Recreation Co. v. Edgerton, 172 App. Div. 464, 15S N. Y. Supp. 421 (4th Dep't 1916); Mressage Photoplay v. Bell, 179 App. Div. 13, 166 N. Y. Supp. 338 (1st Dep't 1917) (film Birth Control, with Margaret Sanger, banned, particularly "in view of the pending war"). In Life Photoplay Corp. v. Bell, 90 Misc. 469, 154 N. Y. Supp. 763 (Sup. Ct. 1915) the court granted an injunction against revocation of the license, on the ground that the film was innocuous.

77. Woods v. Gilchrist, 233 N. Y. 616, 135 N. E. 941 (1922), aff'g, 200 Ajp. Div. 128,192 N. Y. Supp. 417 (1st Dep't 1922); Holly Holding Corp. v. Mross, 270 X. Y. 621,1 N. E. (2d) 359 (1936), aff'g, 246 App. Div. 57, 284 N. Y. Supp. 216 (1st Dep't 1935). But cf. Edelstein v. Bell, 91 MLisc. 620, 155 N. Y. Supp. 590 (Sup. Ct. 1915); Message Photoplay v. Bell, 179 App. Div. 13, 166 N. Y. Supp. 338 (1st Dep't 1917).

78. The deletion or ban must be clearly arbitrary or in bad faith; otherwise the action of the municipal authorities will be upheld. United Artists v. Thompson, 339 III. 595, 171 N. E. 742 (1930); Hutchinson v. Garrity, 218 III. App. 161 (1920), cf. Chiago v. Kirkland, 79 F. (2d) 963 (C. C. A. 7th, 1935) (court will not interfere with finding that play Tobacco Road is indecent). But see Chicago v. Fo: Film Corp., 251 Fed. 883 (C. C. A. 7th, 1918).

79. Taylor, Secret Monic Censors: "Blockade" (1938) 147 NAtro: 38. 
showings in Providence although the first-run showing had been uneventful. The final speech of the film, deletion of which was demanded in Kansas City, read: "It's not war. War is between soldiers. It's murder, murder of innocent people. There's no sense to it." It was a rephrasing of an address made by Pope Pius XI on September 14, 1936. ${ }^{81}$

A Russian picture, Youth of Maxim, was prohibited by the police in Detroit on the ground that it was "pure Soviet propaganda and is likely to instill class hatred and hatred of the existing government and social order of the United States." The ordinance applied only to immoral or indecent films. The Michigan Supreme Court rejected the contention that the word "immoral" could mean "contra to good order or public welfare" and reversed the order. ${ }^{82}$

The Paramount newsreel of the South Chicago strike massacre of Decoration Day, 1937, was banned in Chicago, although it later received nation-wide publicity on being shown before the LaFollette Civil Liberties Committee in the Senate. ${ }^{83}$ The Inside Nazi Germany issue of the March of Time and Professor Mamlock were also forbidden to Chicago movie-goers, although extensive popular indignation induced reconsideration and reversal of the decisions. ${ }^{84}$ In Fall River, Massachusetts, the film Heart of Spain, portraying the modern blood transfusion technique in Loyalist hospitals, was banned by the mayor on the ground that it was "communistic and not for the best interests of this community." 85 These examples are not isolated instances; there are many such actions which receive no record other than castaal mention in the daily press. ${ }^{86}$

In addition to the protection given by state and municipal boards, still another safeguard is afforded the public in the form of subsequent restraint statutes forbidding obscene or indecent entertainments, or the sale or exhibit

80. Civil Liberties Quarterly, Sept. 1938, 4. See also note 79, supra.

81. Stage, Oct. 1938, 54.

82. Schuman v. Pickert, 277 Mich. 225, 269 N. W. 152 (1936); (1937) 7 Detrort L. REV. 48.

83. N. Y. Times, July 3,1937 , p. 5 , cols. $1,6,7$.

84. N. Y. Herald Tribune, Nov. 18, 1938, p. 3, col. 6. See (1938) 55 CrintstinN Century 136; also pamphlet published by American Civil Liberties Union, Morton PicTURe Censorship, Dec. 1, 1938.

85. Newsletter of Civil Lirerties, Massachusetts, Feb. 1938, 1.

86. See generally the files of VARIETY, NEw REPunLic, NATION, and the publical tions of American Civil Liberties Union. In addition to references cited, sce BentaN, Selected Articles on Censorship of the Theatre and Moning Pictures (1931); Ernst, Sense and Censorship, Cinena Arts, July 1937, 18; The Motion Pichure, Censorship or Freedom (1926) 128 Annals 146; Beaufort, Problem of Film Censorship, Christian Science Monitor, Mar. 10, 1939, p. 3, col. 1; NewsweEk, Mar. 13, 1939, 34. The incidence of censorship is particularly high in Quebec, where the Life of Emile Zola was banned, presumably because Zola is on the Index Librortm Prohibitorum. See CurRent History, March, 1939, 47. 
of obscene or indécent pictures. ${ }^{87}$ These statutes, usually declaratury of common law principles, provide for ex post facto punitive measures under the penal code, a violation in most cases being considered a misdemeanor. The owner, distributor or exhibitor of the film, if faced with prosecution, has the opportunity of a trial in open court of the issues involved. Another group of statutes, enacted for the most part in the early days of the film industry, bans motion pictures containing certain specifically enumerated scenes or themes. 88

So long as boards of censorship continue to be active, the develupment of the film industry must suffer. Their standards must be considered while films are being made; they collect a considerable sum annually from the industry in examination fees; and the requirements of examination hefore release of a picture occasion, especially in the case of newsreels, annoying delays. The possibility of forty-eight state boards each with varying procedure and standards, and varying interpretations of those standards, is a cunstant nightmare in Hollywood.

IV.

Conceding for the moment that some form of censorship is necessary, it nevertheless seems obvious that the present multiplicity of ill-equipped state and municipal authorities is a poor solution. If governmental control of any sort is necessary, it seems probable that one federal board could better achieve that purpose. At least it can be said for such a proposal that the present confusion to a large extent would be averted.

Federal regulation of the contents of motion pictures is at present exercised in three ways. A statute of the criminal code, aimed at the men's

87. Cal. Pex. Cone (Deering, 1937) \$311; Conn. Gex. Sr.st. (1930) c. 329, $8 \$ 6244$, 6259; ILI. ANw. Stat. (Smith-Hurd, 1934), c. 3\$, $\$ \$ 46$, 470; Ki:. Rev. Star. A::3. (1935) c. 14, \& 118, c. 21, §1102; Mass. Gex. Laws (1932) c. 272, $\$ 2 \$, 31,32$; Mrm: Stat. (Mason, 1927) c. 98, \$101S7; Mo. Rer. Stut. (1929) c. 30, $\$ 4273$; X. X. Pe:. Law, $\$ \$ 1140$ a, 1141 ; Ohro Gen. Cone Anx. (Page, 1937) $\$ \$ 13035$, 13040; Ore Cone

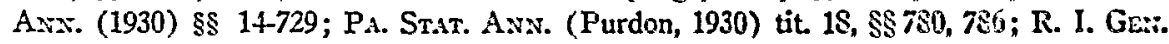
Laws (1938) c. 362, $\$ 9$, c. 610, $\$ 13$; Tex. ANw. PEN. Cone (Vermon, 1938) $\$ 526$; V. CODE AN.. (Michie, 1936) $\$ 4549$.

88. Irt. Axx. Stat. (Smith-Hurd, 1934) c. 3\$, $\$ \$ 471-2$ (films attacling a class of citizens, of any race, color, creed or religion, conducive to riots, or representing the hanging, lynching, or burning of any human being); Iowa CODE (1935) $\$ 13195$ (films of prize fights, or of matches between men or animals prohilited by state law); X(1ss. CODE ANx. (1930) $\$ 1054$ (obscene, indecent or immoral films unless eshibited under the auspices of health authorities for educational purposes); Most. REx. Curs A:m. (1935) $\$ 11567$ (films depicting burglaries, train robberies, or felunies); $\times$. C. Core Axx. (Michie, 1939) $\$ 4349$ a (obscene or immoral films); TEx. PEx. Cone A:iz. (Vernon, 1938) $\$ 612$ (films of prize fights, and obscene films) : Vr. Pen. Laws (1934) $\$ \$ 623$ (obscene or immoral films) ; Wis. SruT. (1937) \$351.38, $\{3$ (indecent, lewd, or obscene films). Exhibitors of The Birth of a Nalion have bren prosecuted in Colorado and New Jersey on the ground that it incites to racial hatred. Cinnexst Histons, Sept. 1938, 45; Civil Llberties Quarterdy, June 1939, 4. 
smoker type of film, forbids the interstate transportation of "any obscene, lewd, or lascivious, or any filthy" motion picture film. ${ }^{80}$ Another statute makes unlawful the importation or interstate transportation of "any film or other pictorial representation of any prize fight or encounter of pugilists, under whatever name, which is designed to be used or may be used for purposes of public exhibition." 90 And under Section 305 of the Tariff Act of 1930,91 the importation of any picture which is obscene or immoral or which advocates treason or insurrection is prohibited. ${ }^{\mathbf{2 2}}$

Numerous attempts have been made to secure the passage of legislation providing for direct federal censorship of motion pictures, but none of the proposed bills has received the approval of Congress. These bills generally fall into two categories: one, those forbidding the interstate transportation of films portraying criminal activities, and two, those setting up a fecleral motion picture commission, empowered to establish standards for the cinema and to license films as a prerequisite to their entering into interstate or forcign commerce. ${ }^{93}$ However, the record of the past twenty years has indicated that censorship by any agency of government impedes both art and expression. Today the industry is effectively demonstrating the superfluity of such control.

V.

At present the only comprehensive centralized agency for control comes voluntarily from Hollywood itself. The organization formally entitled the Motion Picture Producers and Distributors of America, Inc., and known to the industry as the Hays office, was organized in March, 1922, after a wave of reform agitation. Will $\mathrm{H}$. Hays, an Indiana teetotaler and Elder in the Presbyterian Church, who as Republican campaign manager in the 1920 election had elected Warren G. Harding and run up a $\$ 1,200,000$ deficit, wats persuaded to abandon the postmaster generalship in Harding's cabinet to take the presidency of the new organization. His two rivals for the $\$ 100,000$ post

89. 41 Stat. 1060 (1920), 18 U. S. C. $\$ 396$ (1934). See also 35 Stat. 1149 (1909), 18 U. S. C. § 512 (1934). See generally, Legis. (1930) 44 HARv. L. Rev. 113.

90. 37 Stat. 240 (1912), 18 U. S. C. \$ 405 (1934), upheld in Weber v. Freed, 239 U. S. 325 (1915). The mere exhibition of such films is not unlawful. See (1927) 31 LAw Notes 144; (1927) 5 N. Y. L. Rev. 432. An effort was made to repeal this statute in the last Congress. See account of hearings, N. X. Times, May 26, 1939, p. 4, col. 3.

91. 46 Stat. 688 (1930), 19 U. S. C. $\$ 1305$ (1934). Former tariff acts authorized censorship by the Secretary of the Treasury of all films imported from abroad. 38 STAT. 151 (1913); 42 Stat. 921 (1922).

92. But if a film is screened before customs officials and satisfies them that it is not obscene or immoral, it is not thereby exempt from being banned by the New York Board of Censors. Eureka Productions, Inc. v. Lehman, 17 F. Supp. 259 (S. D. N. Y. 1936), aff'd, 302 U. S. 634 (1937). Cf. Eureka Productions, Inc. v. Byrne, 252 App. Div. 355, 300 N. Y. Supp. 218 (3d Dep't 1937).

93. See Legis. (1930) 44 Harv. L. Rev. 113, 117, n. 35; Lewis, The Morton PicTURE INDUSTRY (1933) 370-379. 
had been Herbert Hoover and Hiram Johnson. IVill Hays has been czar of the movies ever since. ${ }^{91}$

The Hays policy, and consequently the policy of the M.P.P.D.A., has been to gain and keep the support of the public by whatsoever means seemed necessary. With the constant backing of all the leading producing and distributing companies, and a membership in 1939 comprising the "Big Eight" Hollywood producers ${ }^{95}$ and some twenty lesser producing units, the Hays office has not been bothered with intra-industry dissent. The methods and means by which the motion picture industry regulates itself through this organization are a part of any account of film censorship.

The scope of the Hays organization as it is at present constituted goes far beyond mere control of the content of films made by its members. ${ }^{00}$ It maintains, besides the head office in New York, branches in Hollywood, VVashington, London, and Paris. Its activities include a title registration bureau, to bring order into the titling process; a conservation department, to eliminate fre hazards; a foreign department, to aid in the distribution of American films abroad; a theatre service department, to assist in the exhibition end of the industry; an advertising advisory council, to insure decency in the advertising of member films; and a community service department, to cooperate with Better Films Councils, schools, churches, universities, and other pullic groups, and to publish a periodic list of Selected Molion Piclures. ${ }^{07}$

It is, however, the Production Code Administration which the public most often associates with the Hays office and which is the essential unit in the campaign to win popular approval for the industry. The idea of regulating the content of films from within the industry did not come into being at the same time as the M.P.P.D.A. Rather it began with a modest list of "don'ts" and "be carefuls" promulgated in 1927.98 Three years later, in January and February 1930, these rules were elaborated into a formal production code, written largely by Martin Quigley, publisher of the Molion Picture Herald, and by Father Daniel A. Lord, S.T., which was ratified ly: the members of the Hays organization on MIarch 31, 1930.03 This fourteen page document, which in some detail enumerated forbidden themes and epi-

94. See generally Will Hays, Furtuse. Dec. 1938, 19 : Redman, Fictures ast Ccusorship, Sat. Rev. of LIT., Dec. 31, 1938, 3; Gilbert, "Cul that Sienc!" six articles, 2d see. N. Y. World Telegram, June 5-10, 1939; WE SAW IT Hapre: (1938) (chapter un Hollywood by Churchill and Nugent).

95. The "Big Eight" motion picture companies: Columbia, Mfetro-Goldwyn-MIayer, Paramount, RKO, Twentieth Century-Fox, United Artists, Universal, and Warner Bros.

96. A description of the MI. P. P. D. A. is contained in (1939) FILs F.cts.

97. See Thorp, AMirrica at the Miovies (1939) 180, 202-3.

98. Quoted in Quigley, Decency IN Motion Plctunes (1937) 41-44. See Mlamm, Hollywood's Move Commandients (1937) 17-19. The caveats of 1927, by excluding profanity, suggestive nudity, childbirth, ridicule of the clergy, etc., provided the framework for the 1930 Code.

99. The Code was ratified by the subsidiary motion ricture producers association Feb. 17, 1930. QuigLEY, op. cit. supra note 98, at 51-2. 
sodes, has been the basis for all subsequent self-regulation in the industry. ${ }^{100}$ Its opening paragraph lays down the principle that "theatrical motion pictures, that is pictures intended for the theatre as distinct from pictures intended for churches, schools . . social reform movements, etc., are primarily to be regarded as Entertainment." The general principles of the Code have been summarized by the MI.P.P.D.A. as follows: " 1 . No picture shall be produced which will lower the moral standards of those who see it. Hence the sympathy of the audience should never be thrown to the side of crime, wrongdoing, evil or sin. 2. Correct standards of life, subject only to the requirements of drama and entertainment, shall be presented. 3. Law, natural or human, shall not be ridiculed, nor shall sympathy be created for its violation." 101

The administration of this Code was haphazard and not too exacting in the years immediately after 1930 . Box office figures were falling, ${ }^{102}$ and producers sought an answer in liberal injections of salacity into their pictures. The novelty of talking pictures, and the influx of new producers in their wake, were other factors in the appearance of films of questionable decency. By 1933 the moral tone of the cinema industry had reached its lowest point since 1922. Popular protests snowballed, but the only group to which the industry paid especial heed was an organization of Catholics called the "Legion of Decency." 103 The Legion of Decency attacked the industry on two fronts; it demanded that movies be "made right'" at the source, and it advocated a boycott of all films of which it did not approve. The Catholic bishops announced that they would order all Catholics to stay away from the unapproved pictures. But by that time the tide had turned in Hollywood.

Faced with a large-scale nationwide boycott, the producers found for the first time that box office meant being decent rather than salacious. And, to insure decency, they voted a $\$ 25,000$ fine against any member of the Hays organization who violated the Code, and established one Joseph Ignatius Breen at the head of a Production Code Administration. ${ }^{104}$ Breen began a system of strict control over the making of motion pictures from the pre-

100. The original Code of 1930 is quoted in MARTIN, op. cit. supra note 98, App. I, 271. It contains six references to divine law. The abbreviated "Particular Applications" of the Code are the rules under which it is administered.

101. Martin, op. cit. supra note 98, at 285; (1939) FilM FAcTs 27. For a study of portrayals of lawyers, judges, and courtroom scenes under the Code, sec (1939) 25 A. B. A. J. 191.

102. Estimated average weekly attendance dropped from 110 million in 1930 to 60 million in 1932 and 1933. (1939) FilM FActs 22.

103. In April 1934, with the support of the Catholic bishops of America, the Legion opened a drive to secure signed pledges to boycott films which the Legion judged offensive. At the height of the campaign 11 million such pledges had been sccurcd. MARTrs, op. cit. supra note 98 , at 33 .

104. See Will Hays, Fortune, Dec. 1938, 68; McEvoy, The Back of Me Hand to You, SAt. Eve. Post, Dec. 24, 1938, 8. Until 1934 the administration of the Code was in the hands of Colonel Jason Joy, executive secretary of the M. P. P. D. A. 
liminary script to the final print, and enforced the Code to the letter. Between 1934 and 1938 his office wrote 26,808 opinions interpreting the Code. ${ }^{105}$ Todny what Breen has to say on an embryonic film may make it or break it; his alone is the authority to give the "purity seal" required of every motion picture to leave Hollywood. ${ }^{106}$

The mechanics of his office are relatively simple. The producers usually seek his advice and consent before buying or developing a book, a play, or an idea for a scenario. ${ }^{107}$ But in any case two copies of the first script of a proposed film are sent to the Breen office, where they are read by two members of his staff and reported on twenty-four hours later. ${ }^{103}$ In the event of disapproval, the producer must either change his script or proceed at his peril, for the finished film must again be reviewed before it receives the requisite seal of approval. There exists a right of appeal to the directors of the M.P.P.D.A. from a ruling of the Breen office, but this has been exercised only seven times since $1934 .{ }^{109}$ For practical purposes a disapproval by Breen is final and binding. ${ }^{110}$

The general theory underlying the Hays office is a face-saving expedient for the industry. By improving the moral tone of the motion picture, it has given the public confidence that the industry is perhaps approaching a longdeferred maturity. It has by the same gesture appeased advocates of an increased legal censorship and satisfied the Legion of Decency.111 By proving

105. (1939) Filas Facts 27. These opinions are written either on a topic for an as yet unproduced film at the request of the producers, or on the secnario or print of a film in production.

106. In 1938 the Production Code Administration approved 545 feature rictures, 49 reissued feature pictures, and 832 shorts. (1939) Frisr Facts 33. In 1937 the features approved were $98 \%$ of all feature pictures exhibited in the United States. Fomre:se, Dec. 1938, 72.

107. Every play on Broadway is reviewed on opening night by a member of Breen's staff, who reports on it according to its suitability for production as a film under the Code provisions.

108. If there is disagreement, Breen usually reads the script himself and makes the final decision.

109. In two of these seven cases, the ruling of the Production Code Administration was modified.

110. In reporting on a script the Breen office gives to the producer extensive advice, which may be separated into four categories. The first is straight disapproval of a line or scene, if it is in contravention of the Code. The second is advice to talie care with a scene, or else it will be disapproved when completed. The third is termed "policy advice," which for example suggests that social workers be presented in a favorable light or that, if the film is to be shown in Central Ameria, the villain must not ba a Miexican. Most practical of Breen's several functions is a foreast of probable action by state or foreign censorship boards, based on a knowledge of the particular vagaries of each board, so that the film may escape official censure. Compliance with the first two categories of advice is necessary if the finished film is to be approved. The latter two are submitted to the producers to save them money and trouble.

111. Films disapproved by the Legion of Decency, and placed in Class C (forbidien to Catholics), have in recent years been almost entirely forcign productions, or inicrior 
that morality was profitable, ${ }^{112}$ it has made the producers feel a responsibility to the public which alone can bring about a satisfactory cinema.

Yet Breen's particular department of the M.P.P.D.A., the Production Code Administration, universally approved on its formation in 1934, had by 19371938 become thoroughly unpopular aniong thoughtful students of the motion picture. A series of innocuous and empty films brought the intellectual prestige of the cinema to a new low. A leading New York critic labelled the motion picture the "ostrich of the arts." ${ }^{113}$ Another noted that a new commandment had been written into the Code: Thou shalt not offend anyone, anywhere, at any time. ${ }^{114}$ The dream world of Hollywood, remote from the reality of 1938, seemed a curiously dull place. The industry, in the words of Archibald MacLeish, had "been so careful not to offend any group of customers that it has ended by boring all groups of customers." 115

The blame for this has been placed in large part on Breen, whose authority was bolstered by his popularity with the Legion of Decency. All theatre chains owned by the large producers refused to show films which dicl not bear the "purity seal," and independent producers were forced to obtain it if they were to secure a profitable release.116 Even those who considered the Code a reasonable and sensible document complained that Breen's application of it was "nothing less than a libel on the average spectator." 117 Any script which touched on controversial or current problems was frowned on by Breen. ${ }^{118}$ Books and plays, hailed by critics and public alike in their original form, met with constant and unconcealed antagonism. ${ }^{110}$

\footnotetext{
"states rights" films without the Breen seal. See annual lists of films approved by the Legion of Decency.

112. Average weekly theatre attendance has increased from 60 million in 1933 to 35 million in 1937 and 1938. (1939) FILM FActs 22.
}

113. Howard Barnes, N. Y. Herald Tribune, Oct. 23, 1938, \&6, p. 1, col. 8 . Of the best 10 films of 1938 picked by Barnes, two were French, five English and only three American. N. Y. Herald Tribune, Jan. 1, 1939, §6, p. 1, col. 8.

114. Redman, Pichures and Censorship, Sat. Rev. of Lit., Dec. 31, 1938, 3.

115. McLeish, Propaganda z's. Hollyzuood, StaGe, Jan. 1939, 11, 12.

116. See Fortune, Dec. 1938, 72.

117. Redman, Pictures and Censorship, Snt. Rev. of Lit., Dec. 31, 1938, 3, 4. Walt Disney on occasion has been forced to veil the udders on his cows.

118. On reading the script for the film Dcad End, the Breen office reported as follows to Samuel Goldwyn: "Page 16, et seq. We would like to recommend, in passing, that you be less emphatic throughout in the photographing of this script in showing the contrast of conditions of the poor in tenements and those of the rich in apartment houses ..." Quoted in McEvoy, The Back of Me Hand to You, Sat. Eve. Post, Dec. 24, 1938, 8, 47. See also Gilbert, "Cut that Scene?" six articles, $2 \mathrm{~d}$ sect., N. Y. World Telegram, June 5-10, 1939. The Hays office is reported to have induced Paramount News to withdraw a newsreel of Wickham Steed, former editor of The Times of London, attacking the British Cabinet after the Munich Pact of Sept. 1938. This action was requested by Ambassador Kennedy, at the urging of the British Foreign Office. N. Y. Times, Oct. 13, 1938, p. 9, col. 3; (1938) 147 Nation 577.

119. See Institute for Propaganda Analysis, Spechal Letter on the Channels of Communication No. 3, July 16, 1938; Redman, Pictures and Censorship, Sat. Rev. of Lit., Dec. 31, 1938, 3. 
A more serious charge levelled at the Production Code Administration was that it was largely a Roman Catholic censorship. ${ }^{120}$ The Code itself was written by two Roman Catholics; ${ }^{\mathbf{1 2 1}}$ the administration was set up at the instigation of the Legion of Decency, a Roman Catholic organization. Breen, a Roman Catholic, administers it with one eye on what the Legion of Decency desires. ${ }^{122}$ He knows that the Roman Catholic Church is fully aware of the incalculable influence of the movies on modern life, and is willing to take the action necessary to see that they are kept on a proper plane. ${ }^{120}$ That this proper plane is not wholly one of morality is indicated by a statement issued by the Legion of Decency on August 22, 1938, saying that it "must oppose the efforts of those who would make motion pictures an agency for the dissemination of the false, atheistic and imnoral doctrines repeatedly condemned by all accepted moral teachers."124

In the past year Hollywood, influenced to an extent by the trend of world events and the loss of foreign markets, has shown signs of returning to themes of contemporary importance. Jteares. the major effort in this direction, was highly successful; Charlie Chaplin's The Griat Dictator and Vincent Sheean's Personal History are now in production. ${ }^{125}$ But the Breen office has not wholly abdicated from its position of no controversy on domestic issues. ${ }^{120}$ Neither has it relaxed its position on sex hygiene; it has refused approval to The Birth of a $B a b y^{12 \tau}$ and, despite the current campaign against the seereey

120. Thorp. Avreruca at the Movies (1939) 2013-215; Redman, Fictures and Consorship. S.tT. Rev, of LiT., Dec. 31, 1938, 3; Bernard Shaw, Film Censorship in the Utitcd States (1936) 34 Lonnon Merctry 490; Yeaman, Cutholit MYuic Censorship (1938) 96 New REPTBLIC 233.

121. Martin Quigley and Father Lord. See p. 103, supra.

122. Breen has warned the producers that, ahove all else, they must not offend the Roman Catholic Church, because, unlike the Protestants, the Catholies ean "licep their people out of the movie houses." McEvoy, The Fack of Me Hand to You, Sar. Eve Post, Dec. 24, 1938, S, 46.

123. See Vigilanti Cura, Excrelical Letrer on Momon Prctures, Pope Pius XI, June 29,1936 , warmly praising the Legion of Decency and requiring the bishops of the Church to obtain pledges from all Catholies nit to attend films disapproved by the Legion.

124. Quoted in Yeaman, Catholic Mosic Censorship (1938) 96 New Rerunuc 233, 235. "The warning to producers is clear. The Catholic Church is the chief guardian of the American screen. The Church will tolerate un that screen other religions but nut, despite the freedom of thought permitted by the American Constitution, any noint of view which seems to run counter to 'traditional morality' as defined by the Catholie Church." ThORP, Axrerici at the Mfoites (1939) 214.

125. Trare, Aug. 7, 1939, p. 24, col. 1; N. Y. Times, Sept. 4, 1939, p. 10, col. 1. John. Mosher in the New Yorker pointed out that ten years ago Itlares would have heen callcd "Maximilian and Carlotta" or just "Carlotta." Trorp, Anerrea ar tre Mfovies (1939) 300.

126. King Vidor, director of The Citadel, an English-made film, has said that the picture could never have been made in Hollywood. Redman, Pictures atd Consurship. SAt. Rev. of LrT., Dec. 31, 1938, 3, 14.

127. The Legion of Decency classified The Birth of a Baby apart from other films, with the observation that it was "unsuitable as entertainment for general theatrical exhibition." Legron of Decexcy, Filars Reviewen, Nor. 1937-Nor. 1939. 
surrounding venereal disease, has forbidden Warner Brothers to mention syphilis in a film honoring the discoverer of its cure. Its basis for prohibiting any topic bearing on sex hygiene is not that it is an improper topic or that it should be forbidden the facilities of the cinema, but rather that such films should not be shown in theatres for profit.

This theory is based on the concept that the motion picture business is strictly an "amusement industry," and not an art or a means of expression. Martin Quigley, one of the writers of the Code, "whose Motion Picturc Herald is to the industry what the London Times is to the British Cabinet," 128 has long sponsored this thesis, that motion pictures should be entertainment and nothing else. The Code and Breen are both in accord with Quigley, and hence the idea of the amusement industry is official despite several recalcitrant producers. ${ }^{129}$ The majority of producers, however, support Breen wholeheartedly, because he has shown them that it will not pay to oppose him and because they prefer entertainment to ideas in the cinema. This fact is important to remember when criticism is levelled at the Breen office: most members of the Hays organization are well satisfied with Breen's work. ${ }^{130}$

The censorship effected by the Production Code Administration is the one thoroughly effective censorship of the motion picture in the United States. By controlling a film while it is being made, by considering primarily the overall effect, rather than subordinate details, the Code is sensible and effective in a way state boards can never be. Self-regulation seems, on the whole, to be an eminently wise and mature step for the industry to take. But when that self-regulation extends itself beyond the appointed fields of decency and good taste, it becomes a stultifying influence on the cinema. ${ }^{131}$

One other major censorship organization is the National Board of Review, which classifies and selects motion pictures on the basis of merit. A pioneer in the field, ${ }^{132}$ the Board derives its income from a charge of $\$ 6.25$ to film producers for every 1000 feet reviewed and from the sale of its literature and services. The Board formerly required deletions in pictures before passing them, but this form of censorship has been entirely abandoned. At present any film is passed which, in the opinion of the reviewers, does not violate the obscenity laws, is not detrimental to public morality, and will not have a stub-

128. Thorp, America at tHe Movies (1939) 268.

129. Notably Walter Wanger. See his address before the American Library Association, June 23, 1939; Wanger, I20,000 American Ambassadors (1939) 18 FoREIGN AfFaIRS 45.

130. At least one Hollywood producer is reputed to have used the Breen office as a convenient pretext for abandoning a film distasteful to him. Communication to YalE LAw Journal from Dudley Nichols, former President of Screen Writers Guild.

131. See Redman, Pictures and Censorship, Sat. Rev. of Lit., Dec. 31, 1938, 3; institute for Propaganda Analysis, Special Letrer on the Channels of CorrMUNiCation No. 3, July 16, 1938.

132. As the National Board of Censorship, it was organized in March, 1909, by the People's Institute of New York City. The present name was adopted in 1916. 
versive effect on large numbers of persons in different sections of the country. The reviewing committee attempts to judge a film "in a common sense way by its probable net moral effect on an audience in a motion picture theatre." 123

VI.

No longer is there any belief that the American people can be legislated into sainthood. ${ }^{134}$ Rather there has been an almost unanimous demand for the abandonment of legal censorship of films. The MI.P.P.D.A. does, of course, resent it. ${ }^{135}$ Also in opposition, both on principle and because they feel it to be a futile and ineffective method of control, are the Legion of Decency and the National Board of Review. ${ }^{130}$

The inability of the censor boards to alleviate the moral lapse of the films between 1931 and 1933 is notorious; if the theme of a film is unfortunate, there is nothing a censorship board can do to improve it. Former Governor Carl Milliken of Maine, now secretary of the Hays office, has expressed the general opinion of the personnel of censor boards. "It is not to be presumed," he said, "that any 3, 5, or 50 persons in this country whose services are obtainable at the salaries paid to censors have the ability to determine what the other 120 million citizens are to see or hear." 137

Strong support to the argument is also lent by the changing character of the films themselves. Agencies of the Federal Government have produced several excellent films. ${ }^{138}$ The documentary cinema is an increasingly inportant branch of the art. Bernard Shaw is writing his own scenarios. 100 Orson Welles is at the head of his own producing unit. ${ }^{140}$ The intellectual quotient of the motion picture seems to be on the rise. ${ }^{141}$

From every standpoint it becomes increasingly obvious that legal censorship of motion pictures must be regarded as undesirable. "It has failed to

133. See pamphlets issued by the National Board of Review of Mfotion Pietures.

134. Lewis, The Motion Picture Industky (1933) 392.

135. See note 137 , infra.

136. Communications to Yale LAw Jounnal from the National Beard of Review and the Legion of Decency. See Quigley, Decency in Mforio: Pictures (1937) 49, 50.

137. Quoted in Lewis, The Mítion Picture Industry (1933) 383.

138. Notably The River and The Plow that Broke the Plains. The Department of the Interior estimates four million people see each of its films; the Department of Agriculture, five million. Thorp, Axrerica AT THE Movies (1939) 251-5. The Administration enlisted the support of the movies for its naval expansion policy of 1938 by offering the use of naval facilities for the desired type of film. Thorp, Asrenca Ar tre Mones (1939) 279.

139. Cf. Pygmalion, Firkr DaIry Year Book (1939) 237, 340. Shaw won the award of the Academy of Mrotion Picture Arts and Sciences for the best screen play of 1938. (1939) Firar FACTS 38.

140. N. Y. Times, Aug. 11, 1939, p. 12, col. 1.

141. See Annual Report of Will Hays to the MI. P. P. D. A., MIarch 27, 1939, quoted in THORP, ANRERTCA AT the MIONEs (1939) 275, which for the first time recognized the value of "pictures that dranatize present-day social conditions." 
recognize and dares not recognize, because it is based on the theory that there are final, unchanging universal standards of good and evil and of good and evil influences, that fundamental in the whole question of the motion picture is a legitimate and inevitable difference of opinion between sections, communities, groups, and individuals." 142

The sensible solution to the question of control of the motion picture wotld appear to be an abandonment of previous restraint censorship in every manifestation, and a reliance on the existing obscenity laws and the proven ability of the industry to regulate itself. The question remains of how best to achieve this end.

The most direct way of abolishing censorship of motion pictures wottld, of course, be to repeal the existing statutes and ordinances. ${ }^{143}$ But this is impractical for two reasons: the popularity of the boards with professional reformers for moral reasons and with legislators for reasons of revente. Also there is the strong probability that a few states and municipalities would retain the censorship notwithstanding its general unpopularity in the country at large. There would always remain the threat that new statutes would be enacted. ${ }^{144}$ And until all film censorship statutes and ordinances are permanently outlawed, the harm they do, and their potentialities for harm, will remain.

A more realistic hope for change lies in launching an attack on the constitutionality of the statutes in an effort to secure reconsideration by the Supreme Court of its decision in the Mutual case. ${ }^{145}$ The industry generally, fearful of a boomerang if such an effort were unsuccessful, and desirous of staying on good terms with governmental bodies, is not over-anxious to bring such a suit; nor is the exhibitor, who at present, under the censor boards, is afforded a practical immunity from criminal prosecution. However, assuming such a suit were brought, one possible line along which this attack might be made would be to urge that motion pictures, in the light of recent decisions of the Supreme Court, ${ }^{146}$ are in interstate commerce. If such be the case, then,

142. Resolution of National Committee for Better Films, affiliated with the National Board of Review, January 1925, quoted in Lewis, The Mfotrow Picture Ininustri (1933) 374.

143. A bill to this end, H.B. 35, was introduced by Rep. Dworkin in the Ohio legislature at its 1939 session, but with no success.

144. In Massachusetts there have been repeated efforts to create a state board of censorship. At both 1938 and 1939 sessions of the legislature two bills creating such a board were unsuccessfully introduced. At the 1939 session both these bills [Sen. B. 106 and H. B. 1896] excluded newsreels from the operation of the proposed board.

145. Mutual Film Corp. v. Industrial Comm., 236 U. S. 230 (1915).

146. Binderup v. Pathe, 263 U. S. 291 (1923); Paramount Famous Lasky Corp. v. United States, 282 U. S. 30 (1930) ; Vitagraph, Inc. v. Perelman, 95 F. (2d) 142 (C. C. A. 3d, 1938), cert. denied, 305 U. S. 610 (1938); Paramount Pictures v. Henneford, 184 Wash. 376, 51 P. (2d) 385 (1935), cert. denied, 298 U. S. 665 (1936). See also Fox Film Corp. v. F. T. C., 296 Fed. 353 (C. C. A. 2d, 1924) ; United States v. First National Pictures, Inc., 34 F. (2d) 815 (S. D. N. Y. 1929), rev'd on other grounds, 282 U. S. 44 (1930). 
it might well be established that the control which the state censor boards exercise is arbitrary and unreasonable, particularly insofar as newsreels are concerned. ${ }^{147}$ Moreover the inspection fees, bearing no reasonable relation to the cost of regulation, might then be held to constitute an unconstitutional burden on interstate commerce. ${ }^{148}$ Another possible line of attack would be to argue that under the criteria required of administrative bodies by recent decisions of the Supreme Court, the censor boards can no longer be upheld as a proper delegation of power in the absence of proper statutory standards and of the safeguards of notice, hearing, and findings. ${ }^{140}$ A petition to the Court to reconsider the Mutual case on this thesis could point out that it is largely res nova; administrative law in its present state was for the most part undeveloped in 1915.

But probably the most desirable method of proceeding, both from the point of view of the likelihood of success and of the future immunity of the cinema, would be to attempt to persuade the Court to bring the motion picture within the constitutional guaranties of freedom of speech and press. ${ }^{150}$ It would seem advisable to make this attempt first on the basis of a newsreel or documentary film, and then, if that were successful, to seek to expand the scope of the ruling to all motion pictures. One critic has remarked that if the question of freedom of the drama were to be tried de novo, without its background of regulation in English and American law, it is quite possible that it would be afforded the protection of the constitutional guaranties. ${ }^{131}$ The motion picture would present an excellent test of this thesis.

147. The requirement of inspection, censorship, and payment of a fee, with the accompanying delay, would seem to be an arbitrary and unnecessary burden on interstate commerce in newsreels. Cf. Baldwin v. Seelig, 294 U. S. 511 (1935).

148. Ingels v. MForf, 300 U. S. 290 (1937); Standard Oil v. Graves, 249 U. S. 339 (1919) ; Foote v. Maryland, 232 U. S. 494 (1914).

149. See Panama Refining Corp. v. Ryan, 293 U. S. 388 (1035); Schechter Corp. v. United States, 295 U. S. 495 (1935) ; Morgan v. United States, 208 C. S. 468 (1936); Morgan v. United States, 304 U. S. 1 (1938). Mfr. Justice Mckenna's observation that the statutory standards of censorship would gain precision frum the sense and experiense of men has not been borne out by the history of the boards. See nute 34, supra. The requirement of reviewing as much as 45 miles of film a weel: of nccessity prohibits any great amount of administrative formality. But in the case of the banning of an entire film it seems that some procedural formality should be observed. See Thayer Amusement Corp. v. Moulton, 7 A. (2d) $6 \& 2$ (R. I. 1939), in which the bamning of a film in Providence with neither hearing nor findings was upheld.

150. Freedom of speech and press are protected from impairment ly the states by the due process clause of the Fourteenth Amendment. Stromberg v. California, $283 \mathrm{C}$. S. 359, 368 (1931) ; Near v. Mínnesota, 283 U. S. 697, 707 (1931); and corporations as vell as persons are protected thereby, Grosjean v. American Press Co., 297 U. S. 233, 244 (1936).

151. Deinard, Some Legal and Historical Aspects of Motion Picture Censorship (Unpublished thesis in Harvard Law School Library, 1922). The tendency of the modern stage to become a sounding board for the discussion of social and economic problems is a 
Assuming a case to be brought on a newsreel or documentary film, the tenor of the argument can be judged from the words of the Supreme Court, that "constitutional provisions do not change, but their operation extends to new matters as the modes of business and the habits of life of the people vary with each succeeding generation." 152 It cannot be supposed that constitutional guaranties are to be limited to forms of publication known at the time the Constitution was adopted, ${ }^{153}$ and it is well to bear in mind that the Supreme Court has not as yet passed upon a case in which speech is an integral part of the film. The cinema of the current generation is as influential a modc of expression, of transmitting information and opinion among citizens, as the press of the eighteenth century. Two opinions handed down by the Supreme Court within the past ten years, Near v. Minnesota ${ }^{154}$ and Grosjcan v. American Press Company, ${ }^{155}$ have affirmed in strong terms the freedom of the press from any forms of previous restraint, the Court speaking in terms of freeclom of expression, of the "right of the members of an organized society, united for their common good, to impart and acquire information about their common interests." 156 The parallel between the newsreel or documentary film and the press has already been noted by the courts. ${ }^{157}$ Certainly it is diffictilt to differentiate the two on any basis other than that of exhibition in a public theatre. Yet the decision in the Hague case ${ }^{168}$ indicates that regulation in fear of disorder is not a valid cause for dispensing with constitutional guaranties. An argument along these lines could not but be highly persuasive. And once the right to freedom of expression in the newsreels had been recognized, the previous restraint exercised by the censor boards would, ipso facto, be unlawful. ${ }^{159}$

strong argument for the immunity of the theatre from previous restraint censorship, if the spirit of the constitutional guaranties is to be preserved.

152. Brewer, J., in In re Debs, 158 U. S. 564, at 591 (1895).

153. For purposes of copyright, motion pictures were early regarded as "writings" under Art 1, \& 8 of the Constitution. Edison v. Lubin, 122 Fed. 240 (C. C. A. 3d, 1903); American Mutoscope \& Biograph Co. v. Edison, 137 Fed. 262 (C. C. D. N. J. 1905); Harper \& Bros. v. Kalem, 169 Fed. 61 (C. C. A. 2d, 1909), aff'd, 222 U. S. 55 (1911); see Burrow Giles Lithographic Co. v. Sarony, 111 U. S. 53, 58 (1884); WEIr, CopYRIGHT LAW (1917) $\$ 491$ et seq.; Note (1922) 71 U. of PA. L. REv. 58.

154. 283 U. S. 697 (1931). See Comment (1931) 31 Cot. L. Rev. 1148.

155. 297 U. S. 233 (1936).

156. Sutherland, J., in Grosjean v. American Press Co., 297 U. S. 233, at 243 (1936).

157. Humiston v. Universal Film Mfg. Co., 189 App. Div. 467, 178 N. Y. Supp. 752 (1st Dep't 1919); In re Appeal from Board of Censors, Phila. C. P. Ct. No. 6, Phila. Legal Intelligencer, Nov. 26, 1937, p. 1, col. 2.

158. Hague v. Committee for Industrial Organization, 59 Sup. Ct. 954 '(U. S. 1939). The possibility of disorder when films are exhibited to a group in a theatre is a frequently heard argument in favor of motion picture censorship.

159. Previous restraint is recognized as an unconstitutional interference with freedom of the press. Patterson v. Colorado, 205 U. S. 454, 462 (1907); Near v. Minnesota, 283 U. S. 697, 713-720 (1931); Grosjean v. American Press Co., 297 U. S. 233, 245-240 (1936). It is assumed that the time of first public exhibition is equivalent to time of publication. 
On this basis it seems quite possible that the Supreme Court would view the holding in the Mutual case as no longer controlling. In view of the advance of the cinema as an educational force, and in view of its position as the one popular source of knowledge common to this country and to the world at large, ${ }^{160}$ such a decision would be an encouragement to the development of the motion picture both as art and as means of communication.

160. The movies, spanning geographic frontiers, today are probably, more than any other single institution, the common denominator of the cultural life of the world. See Thorp, Anrerica at the Movies (1939) 272. 